\title{
АНАЛІЗ НАДАННЯ МЕДИЧНОЇ ДОПОМОГИ ВАГІТНИМ ІЗ СУПУТНІМ ЦУКРОВИМ ДІАБЕТОМ У КЗ ДНІПРОПЕТРОВСЬКА МІСЬКА КЛІНІЧНА ЛІКАРНЯ № 9" ДНІПРОПЕТРОВСЬКОЇ ОБЛАСНОЇ РАДИ
}

\author{
Ю. Л. Удовенко ${ }^{1}$, Н. І. Рега ${ }^{2}$, С. О. Ястремська ${ }^{2}$ \\ ${ }^{1}$ К3 “Дніпропетровська міська клінічна лікарня № 9» \\ Дніпропетровської обласної ради \\ ${ }^{2}$ Тернопільський національний медичний університет \\ імені І. Я. Горбачевського МОЗ Украӥни
}

У статті наведено дані, які характеризують ефективність надання медичної допомоги вагітним із супутнім цукровим діабетом у КЗ «Дніпропетровська міська клінічна лікарня № 9» Дніпропетровської обласної ради, зокрема аналіз кадрового забезпечення, частоту госпіталізації та наявність діабетичних ембріо- та фетопатій.

\section{ANALYSIS OF THE MEDICAL CARE PROVIDED TO PREGNANT WOMEN WITH CONCOMITANT DIABETES MELLITUS AT THE “DNIPROPETROVSK CITY CLINICAL HOSPITAL NO. 9” OF DNIPROPETROVSK REGIONAL COUNCIL}

\author{
Yu. L. Udovenko ${ }^{1}$, N. I. Rega ${ }^{2}$, S. O. Yastremska² \\ ${ }^{1}$ Dnipropetrovsk City Clinical Hospital No. 9 of Dnipropetrovsk Regional Council \\ ${ }^{2}$ I. Horbachevsky Ternopil National Medical University
}

\begin{abstract}
The article analyzes the data characterizing the effectiveness of medical care for pregnant women with concomitant diabetes mellitus at the Dnipropetrovsk City Clinical Hospital No. 9 of Dnipropetrovsk Regional Council, in particular, the completeness of medical personnel, the frequency of hospitalizations and the presence of diabetic embryopathies and phetopathies.
\end{abstract}

Вступ. За даними МОЗ України, екстрагенітальна патологія займає 22,7 \% у структурі материнської смертності. На частку ендокринної патології припадає 6 \% від загальної екстрагенітальної патології, приблизно 1 \% жінок дітородного віку страждає від цукрового діабету (ЦД) ще до вагітності, і у 2-17 \% він розвивається під час вагітності (гестаційний діабет); прогнозують, що до 2030 р. гестаційний діабет буде спостерігатися у 49,3 \% жінок [1]. При ЦД, особливо при гестаційному діабеті, який не лікували, ускладнення вагітності, пологів, порушення стану плода та новонародженого мають місце у 80-93 \% жінок; перинатальна смертність в 5 разів вища, ніж у популяції. Ендокринологічна патологія вагітної тісно пов'язана з вадами розвитку плода. Частота діабетичних ембріопатій (уроджених вад розвитку в дитини, що виникли в ембріональний період) коливається (с) Ю. Л. Удовенко, Н. І. Рега, С. О. Ястремська, 2020 від 3,5 до 8,0 \%, основний фактор ризику - відсутність належної компенсації ЦД у І триместрі вагітності. ЦД залишається найбільш перинатально значущою екстрагенітальною патологією, що супроводжується високими показниками перинатальної смертності. У 1989 р. Сент-Вінсентська декларація однією з основних цілей оголосила зниження перинатальної смертності при діабеті до загальнопопуляційного рівня. Ця мета до цього часу не досягнута [1-5].

Основна частина. Проведено аналіз статистичної звітності лікувального закладу за 2016-2018 рр.

Завдання нашого дослідження:

- проаналізувати якість надання медичної допомоги вагітним із супутнім цукровим діабетом у К3 «Дніпропетровська міська клінічна лікарня № 9» Дніпропетровської обласної ради;

- дослідити проблеми частоти госпіталізації вагітних із супутнім цукровим діабетом; 
- дослідити частоту виявлення патології у новонароджених в КЗ «Дніпропетровська міська клінічна лікарня № 9» Дніпропетровської обласної ради.

3 метою оцінки якості надання медичної допомоги вагітним із супутнім цукровим діабетом у К3 «Дніпропетровська міська клінічна лікарня № 9»
Дніпропетровської обласної ради проаналізовано забезпеченість кадрами, які надають акушерську допомогу, за 2016-2018 рр., зокрема кількість посад у цілому в лікарні та їх зайнятість, питома частка акушерів-гінекологів та середнього медичного персоналу. Результати наведено в таблиці 1.

Таблиця 1. Штатний розпис закладу в 2016-2018 рр.

\begin{tabular}{|c|c|c|c|c|c|c|c|}
\hline \multirow[t]{2}{*}{ Рік } & \multirow[t]{2}{*}{ Посада } & \multicolumn{2}{|c|}{$\begin{array}{c}\text { Кількість посад } \\
\text { у цілому в закладі }\end{array}$} & \multicolumn{2}{|c|}{$\begin{array}{l}\text { У тому числі } \\
\text { в поліклініці }\end{array}$} & \multirow{2}{*}{$\begin{array}{c}\text { Кількість } \\
\text { фізичних осіб }\end{array}$} & \multirow{2}{*}{$\begin{array}{l}\text { У тому числі в } \\
\text { поліклініці }\end{array}$} \\
\hline & & штатних & зайнятих & штатних & зайнятих & & \\
\hline \multirow[t]{6}{*}{2016} & Лікарі, всього & 195,75 & 188,75 & 57 & 57 & 163 & 51 \\
\hline & Акушери-гінекологи & 38,25 & 38,25 & 14 & 14 & 38 & 14 \\
\hline & Педіатри-неонатологи & 9,5 & 9,5 & - & - & 8 & - \\
\hline & Ендокринологи & 10,75 & 10,75 & 2,75 & 2,75 & 11 & 2 \\
\hline & $\begin{array}{l}\text { Середній медперсо- } \\
\text { нал, всього }\end{array}$ & 300,75 & 297,5 & 54,5 & 54,5 & 248 & 49 \\
\hline & Акушери & 48 & 47,5 & 13,5 & 13,5 & 41 & 11 \\
\hline \multirow[t]{6}{*}{2017} & Лікарі, всього & 195,75 & 188,0 & 57 & 56,25 & 162 & 51 \\
\hline & Акушери-гінекологи & 38,25 & 38,25 & 14 & 14 & 39 & 15 \\
\hline & Педіатри-неонатологи & 9,25 & 9,25 & 0 & 0 & 8 & 0 \\
\hline & Ендокринологи & 10,75 & 10,75 & 2,75 & 2,75 & 11 & 2 \\
\hline & $\begin{array}{l}\text { Середній медперсо- } \\
\text { нал, всього }\end{array}$ & 300,75 & 297,25 & 54,75 & 54,75 & 248 & 49 \\
\hline & Акушери & 48 & 47,5 & 13,75 & 13,75 & 41 & 11 \\
\hline \multirow[t]{6}{*}{2018} & Лікарі, всього & 195,75 & 192,5 & 54,75 & 54,25 & 165 & 49 \\
\hline & Акушери-гінекологи & 38,25 & 38,25 & 13,25 & 13,25 & 38 & 13 \\
\hline & Педіатри-неонатологи & 9 & 9 & 0 & 0 & 7 & 0 \\
\hline & Ендокринологи & 10,75 & 10,75 & 2,75 & 2,75 & 10 & 1 \\
\hline & $\begin{array}{l}\text { Середній мед- } \\
\text { персонал, всього } \\
\end{array}$ & 299,75 & 299,75 & 52,75 & 52,75 & 239 & 48 \\
\hline & Акушери & 47 & 47 & 12,75 & 12,75 & 36 & 11 \\
\hline
\end{tabular}

Як видно із таблиці 1, укомплектованість лікарями $\epsilon$ достатньою, а також здійснюється практично без сумісництва (кількість зайнятих ставок відповідає кількості фізичних осіб). Однак дані забезпеченості закладу середнім медичним персоналом ілюструють потребу в кадрових ресурсах, що виражається значною питомою часткою сумісництва із тенденцією до зростання (рис. 1). Практично не вистачає п'ятої частки всіх медичних сестер. Зараз ситуація вирішується за рахунок внутрішнього сумісництва, однак, якщо загальна тенденція не зміниться, то заклад буде відчувати значну потребу в кадрах, зокрема середнього медичного персоналу. Проблема кадрових ресурсів найімовірніше пов'язана із недооцінкою нашим суспільством роботи медичної сестри внаслідок невідповідності затрачених нею фізичних, моральнопсихологічних зусиль і заробітній платі та пакету соціальних послуг, які вона отримує.

Проаналізовано також частоту перебування у стаціонарі вагітних із супутнім ЦД за 2016-2017 рр. (табл. 2).

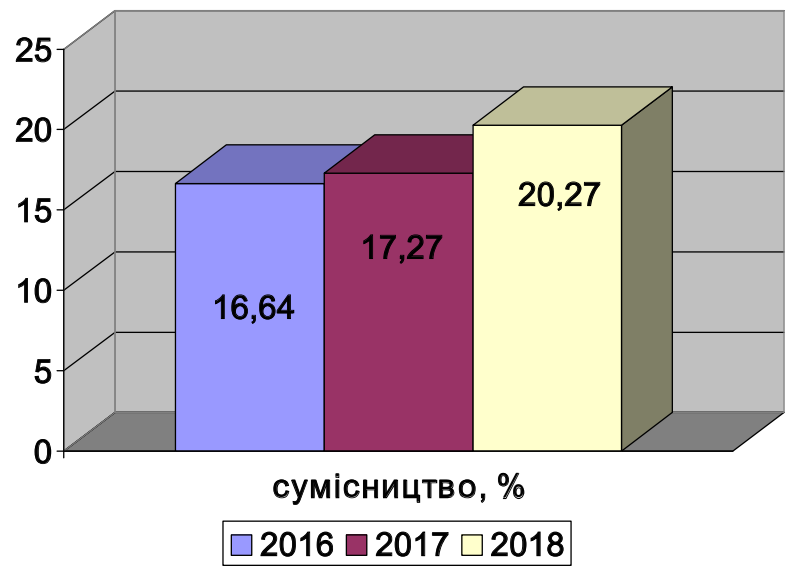

Рис. 1. Динаміка питомої частки сумісництва серед середнього медичного персоналу за 2016-2018 рр.

Як видно із таблиці 2, протягом 2017 р. значно знизилась частота госпіталізації вагітних із ЦД, що пояснюється успішною імплементацією нових стандартів організації амбулаторної акушерсько-гінекологічної допомоги в Україні та стандартизації медичної допомоги при цукровому діабеті 1 типу в молодих людей 
Табличя 2. Склад хворих у стаціонарі

\begin{tabular}{|c|l|c|c|c|}
\hline Рік & \multicolumn{1}{|c|}{ Хвороба } & Виписано хворих & Проведено ліжко-днів & Померло \\
\hline \multirow{3}{*}{2016} & Усього & 16152 & 122560 & 79 \\
\cline { 2 - 5 } & Вагітність, пологи та післяпологовий період & 6015 & 43282 & 1 \\
\cline { 2 - 5 } & Перинатальна патологія & 188 & 1201 & 2 \\
\cline { 2 - 5 } & Цукровий діабет & 1513 & 23072 & 82 \\
\hline \multirow{3}{*}{2017} & Усього & 15333 & 119848 & 3 \\
\cline { 2 - 5 } & Вагітність, пологи та післяпологовий період & 5116 & 44378 & 0 \\
\cline { 2 - 5 } & Перинатальна патологія & 660 & 3696 & 1520 \\
\cline { 2 - 5 } & Цукровий діабет & 320 & 2 & 3 \\
\hline
\end{tabular}

та дорослих. При ефективній компенсації цукрового діабету у вагітних на амбулаторно-поліклінічному етапі різко знизилась потреба в позаплановій госпіталізації.

Нами також проаналізовано склад хворих новонароджених віком 0-6 діб за 2016-2017 рр. (табл. 3).

Виявлено, що у 2016 р. кількість хворих новонароджених значно переважала таку в 2017 р. (268 випадків проти 128). Ці дані корелюють із біль- шою кількістю вагітних пацієнток із супутнім ЦД у 2016 р. Вищенаведені результати підтверджують світові та вітчизняні дані щодо збільшення частоти ембріопатій, фетопатій і патології у новонароджених при наявності супутнього ЦД у матері. Ефективна компенсація цукрового діабету у вагітних на амбулаторно-поліклінічному етапі приводить до зменшення числа патології у новонароджених дітей, які народились від жінок, хворих на ЦД.

Таблиця 3. Склад хворих новонароджених віком 0-6 діб

\begin{tabular}{|c|c|c|c|c|c|}
\hline \multirow{2}{*}{ Рік } & \multirow{2}{*}{ Хвороба } & \multicolumn{2}{|c|}{3 масою 500-999 г } & \multicolumn{2}{|c|}{3 масою 1000 г і більше } \\
\hline & & поступило хворих & померло & поступило хворих & померло \\
\hline \multirow[t]{5}{*}{2016} & Усього & 2 & 1 & 268 & 0 \\
\hline & Уроджені аномалії & 2 & 1 & 20 & 0 \\
\hline & Синдром дихальних розладів & 2 & 1 & 29 & 0 \\
\hline & Гіпоксія та асфіксія & 0 & 0 & 30 & 0 \\
\hline & Інші хвороби & 0 & 0 & 0 & 0 \\
\hline \multirow[t]{5}{*}{2017} & Усього & 2 & 1 & 128 & 2 \\
\hline & Уроджені аномалії & 0 & 0 & 23 & 1 \\
\hline & Синдром дихальних розладів & 2 & 1 & 24 & 1 \\
\hline & Гіпоксія та асфіксія & 0 & 0 & 24 & 0 \\
\hline & Інші хвороби & & & & 0 \\
\hline
\end{tabular}

Висновки. 1. Цукровий діабет залишається актуальною перинатально значущою екстрагенітальною патологією, яка супроводжується виникненням ембріопатій, фетопатій і патології у новонароджених.

2. Імплементація нових стандартів організації амбулаторної акушерсько-гінекологічної допомоги

\section{СПИСОК ЛІТЕРАТУРИ}

1. Вплив цукрового діабету на перебіг вагітності, розродження та перинатальну смертність / М. В. Макаренко, Д. О. Говсєєв, Я. М. Гулам [та ін.] // Здоровье женщины. 2016. - № 1 (107). - С. 40-44.

2. Про організацію амбулаторної акушерсько-гінекологічної допомоги в Україні. Додаток 13. Скринінг на гестаційний діабет : наказ МОЗ України від 15.07.2011 р. № 417.

3. Про затвердження та впровадження медико-технологічних документів зі стандартизації медичної допомоги з початкової, реанімаційної і післяреанімаційної допомоги новонародженим в Україні : наказ МОЗ України від 28.03.2014 p. № 225. в Україні та стандартизації медичної допомоги при цукровому діабеті 1 типу в молодих людей та дорослих приводить до зниження частоти госпіталізації вагітних із ЦД та зменшення числа патології у новонароджених.

4. Про затвердження та впровадження медико-технологічних документів зі стандартизації медичної допомоги при цукровому діабеті 1 типу у молодих людей та дорослих : наказ МОЗ України від 29.12.2014 р. № 1021.

5. Ізбицька Н. Г. Вагітність та цукровий діабет: клініка, діагностика та лікування : навчальний посібник для самостійної роботи студентів V-VI курсів медичного факультету та лікарів-інтернів акушерів-гінекологів, ендокринологів, неонатологів / Н. Г. Ізбицька, С. П. Онопченко. - Запоріжжя : ЗДМУ, 2015. - 80 с.

Отримано 23.03.20 